\title{
ВИМОГИ ДО МЕДИЧНОЇ ІНФОРМАЦІЙНОЇ СИСТЕМИ З ПОЗИЦІї ЛІКУВАЛЬНОГО ЗАКЛАДУ
}

\author{
О. М. Стадник, О. Б. Блавацька \\ Львівська обласна клінічна лікарня \\ Львівський національний медичний університет ім. Данила Галицького
}

\begin{abstract}
The present development of the IT industry and the undeniable benefits of new technologies application in all spheres of human activity, the needs for introduction and improvement of modern information technologies in medicine become obvious. There is no doubt, that this, in turn, would improve the quality of health services, reduce the cost of treatment and diagnostic process, speed up the collection, processing and analysis of statistical data, facilitate cooperation between medical institutions. Nowadays in Ukraine there are several problems, which complicate the development and implementation of health information systems: the lack of legal support, high cost of software products for medical institutions, the lack of a unified functional product, recommended for use.
\end{abstract}

На сьогодні в Україні продовжується активна робота щодо запровадження електронних реєстрів $\mathrm{i}$ документів, зокрема медичних, для оптимізації їх обліку та можливості ширшого і швидшого застосування при наданні медичної і фармацевтичної допомоги. Це особливо актуально у зв'язку з першими кроками у відшкодуванні вартості фармакотерапії, а також лікування при медичному страхуванні (MC).

Проте на практиці виникають численні проблеми в рамках експериментальних пілотних проектів. Це, насамперед, незацікавленість і навіть опір медичного персоналу лікувально-профілактичних установ (ЛПУ) через нерозуміння ефективності від впровадження медичних інформаційних систем (МIC), дороговартісні програмні продукти, а також цілком обгрунтована недовіра через фактичну незахищеність інформації. Крім того, ще можна зазначити певну несумісність інформаційних систем, як в технічних аспектах, так і в медичних, соціальних та фінансових нормах і правилах.

У процесі вивчення проблеми визначено 5 основних ключових аспектів, які мала б забезпечувати ефективна та функціональна медична інформаційна система (МIC). Якими є основні напрямки розвитку інформаційної системи?

Юридичний: відповідність існуючій законодавчій базі, що регулює створення, облік та життєвий цикл електронного документообігу [2]; забезпечення конфіденційності медичної інформації [1]; захист персональних даних пацієнтів [3]; ведення державною мовою.

Організаиійний: сумісність програмного забезпечення; робота комп'ютерної мережі в режимі on line; наявність автоматизованого робочого місця (АРМ) для лікарів, медсестер, статистиків, інших медичних працівників; автоматичне формування графіків прийому всіх спеціалістів в стаціонарах, поліклініці, діагностичних та лікувально-допоміжних відділах, лабораторіях, графіків проведення оперативних втручань тощо [7].

Статистичний: дистанційний збір статистичної інформації; автоматичне формування облікових та звітних форм, їх друкування; формування аналітичних таблиць в усіх необхідних розрізах; створення бази даних пацієнтів з метою пошуку інформації стосовно стану здоров'я, часу перебування в лікувальній установі тощо, починаючи з приймальних відділень, через структурні підрозділи, де ця інформація вводиться, та закінчуючи сервером у інформаційному центрі; створення бази медичних даних з метою пошуку статистичної інформації [8].

Медичний: формування стандартизованих протоколів обстеження, лікування, оперативного втручання із записом в усі необхідні документи, виведення даних в усі облікові та звітні форми; формування медичної документації; можливість порівняння клінічних даних в динаміці упродовж тривалого часу; накопичення наукової інформації, проведення ііі аналізу, можливість обміну з іншими медичними установами, ВУЗами, інститутами;. можливість створення медичного інформаційного центру, де зберігатиметься інформація щодо новітніх методик лікування, оперативних втручань, мультимедійні та графічні дані, медична бібліотека, статті тощо.

Фінансовий: проведення калькуляції та розрахунок кошторису медичних послуг; розрахунок вартості медикаментів, розхідних матеріалів, можливість дистанційного замовлення необхідних медикаментів; можливість проведення розрахунків зі страховими компаніями за надані послуги; можливість калькуляції вартості лікування пацієнтів з інших областей чи країн.

В межах ЛПУ використання даної системи повинно бути вигідним та ефективним для усіх іï учасників.

(c) О. М. Стадник, О. Б. Блавацька 
Якими є очікувані результати впровадження інформаційної системи?

Для пацієнтів: скорочення термінів надання невідкладної допомоги; зменшення часу обстеження хворих при планових відвідуваннях поліклініки i/aбо при поступленні в стаціонар; автоматизований запис на прийом до спеціалістів з метою консультації, для проведення обстеження, процедур; збільшення доступності консультативної спеціалізованої допомоги для пацієнтів віддалених місцевостей і/або при необхідності додаткових консультацій у складних діагностичних випадках; скорочення часу на проведення додаткових досліджень чи обстежень; оперативна видача виписної та іншої медичної документації.

Для лікарів: ведення електронної версії «Медичної карти стаціонарного / амбулаторного хворого» в частині, що перебуває в компетенції лікуючого лікаря; оперативна передача даних про пацієнта в процесі його перебування у стаціонарі у відповідну медичну документацію; автоматизоване внесення / надходження інформації про пацієнта в частині, що перебуває в компетенції іншого медичного персоналу - медсестер, лікарів-діагностів тощо; формування стандартизованих протоколів обстеження, лікування, оперативного втручання із записом у відповідні документи; можливість порівняння клінічних даних в динаміці протягом тривалого часу; збільшення часу на обслуговування пацієнтів за рахунок скорочення часу, що витрачався на передачу даних чи документації, висновків консультацій чи результатів проведених обстежень; автоматичне формування графіків прийому всіх спеціалістів в стаціонарах, поліклініці, діагностичних відділах, лабораторіях, графіків проведення оперативних втручань тощо; накопичення інформації та можливість обміну нею з метою проведення наукових чи клінічних досліджень; впровадження в практику нових методів діагностики та лікування; друкування необхідної виписної та облікової документації.

Для адміністрації: здійснення взаємозв'язку усіх структурних підрозділів безпосередньо через комп'ютерну мережу в режимі on line; структурування хаотичного потоку хворих між стаціонарними відділеннями та діагностичними підрозділами; фор-

\section{Лiтература}

1. Закон України № 80/94-ВР від 05.07.1994p. «Про захист інформації в інформаційно-телекомунікаційних системах» ВР України. Режим доступу: http://zakon4.rada.gov.ua/laws/ show $/ 80 / 94-\% \mathrm{D} 0 \% \mathrm{~B} 2 \% \mathrm{D} 1 \% 80$.

2 Закон України № 851-IV від 22.05.2003 - «Про електронні документи та електронний документообіг» ВР України. мування облікової документації, звітних даних; оперативний аналіз статистичної інформації з можливістю прийняття ефективних управлінських рішень; проведення контролю діяльності кожної служби оn line чи за результатами певного звітного періоду; економія коштів на закупівлю паперових носіїв документаціі; впровадження калькуляції медичних послуг; розрахунок вартості медикаментів, розхідних матеріалів; можливість дистанційного замовлення необхідних медикаментів для стаціонарних хворих; сприяння впровадженню МС з використанням автоматизованого підрахунку витрат на утримання та лікування хворих; можливість проведення розрахунків зі страховими компаніями за надані послуги.

Опрацювання всіх названих проблемних питань повинні бути обов'язковим елементом розробки спеціалізованого програмного забезпечення для закладів охорони здоров' я.

За багато років, упродовж яких нам пропонують програмні продукти, так і не враховано взаємозв' язків лікувальних і фармацевтичних закладів щодо медикаментозного забезпечення лікувально-діагностичного процесу, фінансові обгрунтування, можливі нюанси страхових випадків $[4,5,6]$. Для повноцінного запровадження страхової медицини необхідне чітке функціонування єдиної МIC, яка уможливить не тільки соціальний та страховий моніторинг, а й комплексне використання баз даних, стандартів лікування та результатів фармакоекономічного аналізу, зокрема, впливу на бюджет.

Висновки. Як свідчить досвід російських колег, процес розробки та впровадження єдиної MIC не може бути поспішним [9]. Усі проблеми треба і можна вирішувати. У практичних менеджерів О3 є бачення стосовно досягнення поставлених завдань 3 метою забезпечення ефективності та функціональності медичної інформаційної системи, є бажання до співпраці з виробниками спеціалізованого програмного продукту. Крім того, можна із впевненістю стверджувати, що є усвідомлення необхідності такого прикладного застосування інформаційних технологій. Результатом цього, поза сумнівом, буде підвищення соціальних стандартів та якості життя населення.

Режим доступу: http://zakon2.rada.gov.ua/laws/show/851-15. 3 Закон України № 2297-VI від 01.06.2010 року «Про захист персональних даних». ВР України. Режим доступу: http:// zakon4.rada.gov.ua/laws/show/2297-17/page.

4. Качмар В. Медичні інформаційні системи - стан розвитку в Україні // Український журнал телемедицини та ме- 
дичної телематики. - Донецьк. - 2010. - Т.8, № 1.

5. Коваленко А. Проблемы стандартизации в области медицинских информационных технологий / А. Коваленко, А. Пезенцали, Е. Царенко // Клиническая информатика и телемедицина. -2011.-Т. 7, № 8.-С.111-113.

6 Ковтонюк П. Медичні інформаційні системи: яка підходить вам? / Ковтонюк П., Бондаренко К. // РRO-менеджмент в охороні здоров'я. - Київ - № 3. - 2012. - С. 32-39. 7 Наказ МОЗ України №127 від 21.05.1998 р. «Про створення Єдиного інформаційного поля системи охорони здоро- в'я України» Режим доступу: http://zakon.nau.ua/doc/ ?code $=$ v0127282-98.

8. Наказ МОЗ України №330 від 05.07.2005 р. «Про запровадження ведення електронного варіанту облікових статистичних форм в лікувально-профілактичних закладах». Режим доступу: http://www.moz.gov.ua/ua /portal/ dn 20050705 330.html.

9. Схема информатизации здравоохранения: что мы получим за 100 млрд. рублей // C-NEWS. -Москва. - 2013. - № 66. - С. $30-42$. 